\title{
From innovation to commercialization through networks and agglomerations: analysis of sources of innovation, innovation capabilities and performance of Dutch SMEs
}

\author{
Patricia van Hemert • Peter Nijkamp • \\ Enno Masurel
}

Received: 6 August 2011 / Accepted: 9 December 2011 / Published online: 2 August 2012 (C) The Author(s) 2012. This article is published with open access at Springerlink.com

\begin{abstract}
This study claims that policy makers may not be sufficiently aware of the importance of maintaining an appropriate balance between exploration and exploitation networks for small and medium-sized enterprises (SMEs). On the basis of the open innovation model, policy makers are also increasingly stimulating SMEs to develop their exploration skills. In the Netherlands, a government subsidy called the 'innovation voucher programme' was introduced to stimulate SMEs to develop innovation in cooperation with knowledge institutes. Yet, although many studies show that SMEs tend to have a higher R\&D productivity than larger firms, and innovative SMEs are more likely to make external networks with other SMEs or institutions such as universities, there is still little examination of the successfulness of SME's innovation activities. The growing policy attention for the role of SMEs in innovation prompts the questions how innovation in SMEs can be facilitated, and which factors contribute to the success (or failure) of their innovation efforts. This study explores the innovation strategy of innovative Dutch SMEs by means of their sources of innovation, innovation capabilities, innovation performance, and commercialization sources. By means of structural equation modelling of a sample of 243 Dutch SMEs, this study shows that exploring (technology) opportunity together with institutions such as universities and private research establishments is important for successful innovation in SMEs.
\end{abstract}

\footnotetext{
P. van Hemert $(\varangle) \cdot$ E. Masurel

ACE Center for Entrepreneurship, VU University Amsterdam, De Boelelaan 1085,

1081 HV Amsterdam, The Netherlands

e-mail: p.p.van.hemert@vu.nl

E. Masurel

e-mail: e.masurel@vu.nl

P. Nijkamp

Department of Spatial Economics, VU University Amsterdam, De Boelelaan 1105, 1081 HV Amsterdam, The Netherlands

e-mail: p.nijkamp@vu.nl
} 
But, in addition, our model shows that contacts with competitors are also important for successful innovation performance. Our finding that openness of open innovation also applies to the commercialization phase is too often neglected by researchers and policy makers.

\section{JEL Classification $\mathrm{C} 38 \cdot \mathrm{D} 83 \cdot \mathrm{O} 30 \cdot \mathrm{O} 31 \cdot \mathrm{O} 52$}

\section{Introduction}

The idea that innovation is best understood as a diffusion process, where ideas and inventions are formed largely within firms or by entrepreneurs in isolation from the external world, is losing ground. Innovation has traditionally been modelled as a process where scientists or researchers try to solve well-defined problems by performing experiments in confined arenas such as laboratories or test sites. Particularly in the period after the Second World War, industry barriers and products in relation to a predefined demand structure were key factors for strategy and innovation. This industry approach with a strong focus on industries and value-chains (Porter 1980, 1985) is increasingly being questioned. Porter's model (Porter 1990) emphasizes market and competition rather than networking and social interaction as success factors for clusters of innovation and shows only a marginal interest in the regional dimensions of innovation (Moulaert and Sekia 2003). However, the global business landscape has changed dramatically during the last 30 years, and a mere focus on technological innovation is not sufficient to understand innovation processes in the new business landscape. The idea is gaining ground that innovation activities are organized not only within but also across firm boundaries, and that actors co-create innovative products, services or processes that generate value in value constellations (Norman and Ramirez 1993). Actions and not structures lie at the heart of understanding innovation phenomena (Arvidsson and Mannervik 2009). To improve our understanding of innovation processes, focus should thus be much more on the socio-technical perspective and the role of business networks (Geels 2004; Schilling and Werr 2009; Arvidsson and Mannervik 2009). In this paper, we particularly aim to understand the innovation actions and activities of innovative Dutch small and medium-sized enterprises (SMEs), whereby we do not limit the analysis to a particular industry and its surrounding cluster. Instead, we focus on the innovation system as such which may include several industries and does not limit the analysis to the birth, growth and decline of one particular industry or cluster.

Innovation processes today rely on communication and interaction with critical actors outside their own company. Such dynamic processes are generally evaluated within the frameworks of national innovation systems (NIS) and regional innovation systems (RIS). National innovation systems are defined as the flows and mechanisms of technology and information between people, enterprises, and institutions that are the key to the innovation process at the national level (OECD 1997). Various researchers quickly applied the NIS concept in studying RIS (Braczyk et al. 1996; Cooke et al. 1997; Morgan and Nauwelaers 1999; Koschatzky et al. 2000; Cooke 2001; Doloreux 2002). The RIS more specifically examines innovating firms in the context of external institutions, government policies, competitors, suppliers, 
customers, value systems, and social and cultural practices that affect their innovation activities within a geographical area larger than a city, but smaller than a nation (Kumaresan and Miyazaki 1999; OECD 1999). Increasingly studies in the existing literature are addressing the empirical discussion on how firms can interact with the RIS by utilizing sources of information (SI) available within an RIS (Yam et al. 2011). At least three forms of knowledge spillovers can be distinguished (Boschma and Frenken 2006): spin-off firms, labour mobility, and R\&D collaboration. These topics have been addressed systematically in empirical research (Uzzi 1996; Almeida and Kogut 1999; Breschi and Lissoni 2003; Giuliani 2007; Klepper 2007; Ponds et al. 2007; Morrison 2008). In particular, two findings stand out (Burger et al. 2009): (1) firms in economic agglomerations do not profit automatically from co-location, because spillovers occur mainly between firms with strong social network relations; and (2) a substantial part of spillovers takes place over longer distances, as firms have many network relations outside the agglomeration in which they are located. Networks of economic actors (firms, researchers, inventors, employees) can thus be regarded as the most accurate unit of analysis to trace the actual exchange (flows) of knowledge, labour or intermediate goods in economically agglomerated spaces (i.e. regions).

Firms in today's global economy base their actions on collaboration and servicebased components when developing new strategies. Although these mechanisms are increasingly recognized, in today's literature they are usually researched independently, if at all. This study aims to adopt an integrated approach and build a model of territorial innovation by means of structural equation modelling (SEM) that addresses both the collaboration and the services-based components of 243 innovative Dutch SMEs. What is often overlooked in innovation literature is that in a service-based economy, the fundamental focus of business activities within the network is to create products or services that generate value for the customers who purchase them (Arvidsson and Mannervik 2009). Value can be of different types: for example, when a firm relieves another actor from having to operate certain activities, or when a product or service enables the customer to achieve results that otherwise would have been impossible (Normann 2001). Generally, value is best understood and analysed from the customers' perspective. However, the provider of a product or service has to lead and organize a network of actors to make the offering attractive (Ramirez and Wallin 2000). It is thus the product or service that organizes action in the collaborative process, where learning is the most important driver. Customers co-create services, but other actors such as competitors also influence the offering via their simultaneous actions (Normann 2001; Normann and Ramirez 1998; Grönroos 1982). This study will particularly highlight the latter form of co-creation.

\section{Firms' learning process for growth and renewal}

A new understanding of innovation systems needs to acknowledge today's social and economic realities and dynamics. Arvidsson and Mannervik (2009) refer in this respect to Eliasson (2000) who has developed and outlined clear characteristics of experimentally organized economies based on the notion of open systems and creative destruction. He follows Schumpeter's (1934) view on innovation and creative destruction, which implies an open system approach (Katz and Kahn 1966) and that 
economic actors operate in turbulent environments (Emery and Trist 1965). Eliasson (2000) developed five characteristics that: (1) centre around the ideas of a knowledgebased information economy where people are regarded as boundedly rational (Cyert and March 1963), and (2) hold tacit knowledge (Polanyi 1969) and act from what they believe is right. The system they operate in is (3) open, and development is characterized by Schumpeter's process of creative destruction. Further, (4) there are supportive competences and institutions that create competence blocks suitable for global and local demand. But there are also institutions of all sorts that allow and stimulate new ideas and do not oppose anything that challenges the current norms and ideas. Finally, (5) social capital (Putnam 2000) is present to stimulate meetings and open discussion leading to the exchange of ideas and learning. From this perspective, an innovation system primarily consists of actors that offer services that are processes that consist of a set of activities that take place in interactions between a customer and people, goods and other physical resources, systems and/or infrastructures representing the service provider, and possibly involving other customers, who all aim at solving customers' problems (Grönroos 2006).

Schumpeter (1934) had already defined that the exploration of new opportunities and the exploitation of old certainties as well as the inherent conflict of the two lie at the heart of organizational change and learning. Arvidsson and Mannervik (2009) in their study suggest the use of these two different types of change processes to better understand change dynamics in open systems. In Table 1, these two processes are outlined in more detail. According to this definition, exploration concentrates on the recognition and development phase of innovation, while exploitation focuses on the production and commercialization phase. March (1991) further highlights that systems that engage in exploration without exploitation will most likely deal with the costs of experimentation without gaining much of its benefits. At the same time, systems that exploit without a distinct exploration phase are likely to find themselves trapped in a suboptimal state of stable equilibria without much gain in the long run. As a result, over the long run, efforts to stimulate both change processes are crucial for survival and prosperity. Exploration is needed to renew the system, but it is only through exploitation that the benefits of renewal are reaped (March 1991). In models like those of Porter (1990), the process of exploration tends to get blocked due to the strong focus on rational decision-making processes in firms and among other economic actors, which highlights competition rather than cooperation and, as a result, ignores the evolutionary aspect of growth and decline. In this respect, the historical case studies

Table 1 Characteristics of exploration and exploitation

Source: March (1991)

\begin{tabular}{ll}
\hline Exploration & Exploitation \\
\hline Search & Refinement \\
Variation & Choice \\
Experimentation & Production \\
Play & Efficiency \\
Flexibility & Selection \\
Discovery & Implementation \\
Innovation & Execution \\
\hline
\end{tabular}


of Arvidsson and Mannervik (2009) showed that actors in the Swedish biomedicine, biomaterial and IT systems wanting growth were found to fight for resources against actors wanting renewal. In the research process, Arvidsson and Mannervik (2009) witnessed clear and shared patterns of growth and renewal in specific time periods, and periods of tension and almost competition for critical resources between proponents of each of the two processes in other periods. However, over the long run, both types of actors needed each other.

This study bases itself on the notion that the two change processes, exploration and exploitation, are essential for growth and renewal in a system, whereby a system stands for a firm's innovation system, and also the regional and national innovation system. The best design of the context will depend on the critical needs of the innovation system, that is which kind of dynamics that are currently dominating the system. Within a system, we further recognize that exploration and exploitation should not substitute but rather complement each other. We believe that this is a mind-set concerning how innovation happens that is not sufficiently highlighted in the current innovation studies. Researchers and policy makers often tend to have a one-sided focus, either highlighting demand factors such as consumer behaviour or focusing on supply factors such as R\&D and education, a direction that more directly reflects the European Union's innovation ambition. This study aims to show that the change processes exploration and exploitation do indeed complement each other, both within the firm and on a regional and national level as a result of the current economic realities with specialized companies, network-based cooperation, open source innovation and increasing customer influence. This study contributes to the literature that challenges Porter's cluster model by highlighting the dynamics of innovation in large industrial or business systems in relation to a social context. Further, deepening the understanding of the characteristics of exploration and exploitation can help researchers and policy makers to improve systems that help to stimulate growth and renewal.

\section{The regional innovation system, SMEs' innovation capabilities and sources of knowledge}

In this study, the RIS is regarded as the implementation strategy that examines more closely the generation and diffusion of knowledge among actors that take place outside the boundary of the firm. The actors are considered to interact most extensively on a regional level (Romijn and Albaladejo 2002; Colaghirou et al. 2004; Crescenzi and Rodriguez-Pose 2011). The boundary of an RIS may be drawn conceptually and organizationally around the economic, social, political and institutional relationships that generate a collective learning process within a related group of technological and functional areas. This is particularly true for small and medium-sized enterprises (SMEs). When linked to firm innovation systems, however, the results can provide research background for the study of NIS, to the extent that the results can describe the link between innovation and competitive economic outcomes at the national level which can be useful for the national science and technology research domain. Considering that exploration and exploitation are essential for growth and renewal, we believe a firm's innovation system should at least consist of the components described in the Sects. 3.1-3.3 below: 


\subsection{SME's innovation capabilities (IC)}

Innovation capabilities (IC) ${ }^{1}$ are defined as a comprehensive set of firm characteristics that facilitate and support the firm's innovation strategies (Burgelman et al. 2004). Colaghirou et al. (2004), among others, showed that both firm and innovation capabilities and openness towards knowledge sharing are important in bolstering innovation performance. This is specifically true for SMEs that are generally considered to lack sufficient financial and human resources to solely rely on internal processes. The firm innovation system can be defined as an interactive process that involves the generation, adoption, implementation, and incorporation of new ideas and practices within the firm (van de Ven et al. 1989; Carlsson et al. 2002). Innovation activity within a firm is an interactive process characterized by technological interrelatedness between various sub-systems or sub-processes (Teece 1996). These sub-processes include those of concept generation, product development, production, technology acquisition, leadership, resource provision, and system and tool provision. IC can be enhanced by developing the firm's ability in each sub-process. Various studies have sought to identify the IC components that are important to firms (Adler and Shenbar 1990; Christensen 1995; Yam et al. 2011). It is recognized that a firm with greater IC is able to achieve higher levels of organizational performance and effectiveness.

\subsection{Source of knowledge (SI)}

Central to the system of innovation approach is the idea that innovation should be seen as an evolutionary, non linear, and interactive process requiring intensive interaction with different actors in the RIS such as suppliers, customers, and even competitors, as well as other organizations (Tödtling and Trippl 2005) such as universities, research centres, educational institutions, financing institutions, standard-setting bodies, and industry associations. The generation and utilization of knowledge depend on the frequency and density of the firm's interactions with external sources of innovation and its openness to external knowledge. Innovation can be conceptualized as a learning process (Cohen and Levinthal 1989; Garvin 1993; Dodgson 1993; Hitt et al. 2000). Besides generating knowledge through internal R\&D departments, firms, in particular SMEs, can grow their knowledge and absorptive capacity by acquiring external knowledge bases (Cohen and Levinthal 1989; Huber 1991). The focus in this study is, therefore, in particular on the firm's interaction with external sources of innovation (SI) in the region in which the firm operates. Defining the source(s) of innovation is important because it determines the capabilities that a firm must possess to adopt the necessary innovations in time to achieve success in the marketplace. As such, a critical component of successful innovation is the ability of a firm to exploit and utilize external knowledge in the RIS (Lin et al. 2002). Many studies have considered the impact of external knowledge bases or SI on the innovation performance of a firm

\footnotetext{
1 The literature usually refers to technological innovation capabilities (TIC). In this study we have chosen to use the broader term innovation capabilities (IC), which better fits the broader interpretation of innovation activities employed by the SMEs in the survey conducted for this study.
} 
(Uzun 2001; Tödtling and Trippl 2005). However, few prior investigations have found that the firm's ICs are enhanced by utilizing SIs within the RIS (Yam et al. 2011).

\subsection{Commercialization sources (CS)}

This paper considers commercialization at the firm level as an essential part of the system of innovation approach. Knowledge commercialization (exploitation) is generally described as an actor's deliberate commercializing of knowledge assets to another independent actor, involving a contractual obligation for compensation in monetary or non-monetary terms (Lichtenthaler 2005; Boyens 1998; Ford and Ryan 1981). Research and practice often focus on the monetary aspects of commercialization, but strategic objectives such as realizing learning effects are considered increasingly important (Davis and Harrison 2001; Rivette and Kline 2000). The actual transfer of the knowledge assets constitutes only the final step of the commercialization process. However, a complete picture of external knowledge exploitation requires a comprehensive picture of the activities and capabilities that are needed for commercializing firm knowledge. Knowledge generated in firms needs to be transformed and/or transferred in order to design, produce, sell, adopt and implement customer-oriented applications. In particular for SMEs, this trajectory is often an interactive process of value creation and realization, whereby a complete palette of competencies and actor interactions between knowledge institutions, companies and others (interest groups, industry organizations and governmental organizations) is necessary to complete this value-adding process. Commercialization sources like customers, partners, suppliers and knowledge institutions are, due to their small size and limited financial resources, of vital importance for SMEs in order to integrate, combine and apply knowledge to generate commercially viable offerings. Increasingly, this is also the case for other economic actors due to intense market dynamics, which forces firms to adopt the open process of innovation and be more flexible and adaptable to interact with external actors. In this respect, analysis of the commercialization sources of innovative SMEs can increase understanding of efficient innovation strategies.

\section{The regional innovation system in the Netherlands}

In the Netherlands, innovation only became a serious policy issue after the Lisbonagenda of 2000 was launched. Before 2000, the economic strategy particularly focused on wage moderation and organized labour market flexibility. This is a strategy better known as the 'polder model' (Visser and Hemerijck 1997). This 'polder model' led to a homogeneous policy approach towards sectors, and widespread and influential networks of trade unions. In 2003, with the launch of the Innovation Platform, a policy more focused on strengthening industry and innovation was introduced in the Netherlands.

\subsection{Dutch innovation platform (innovative platform)}

With the launch of the Innovation Platform, the Netherlands shifted policy attention towards an economy-wide approach that focused more on the Dutch sector 
structure. In 2004, on the basis of a call to 113 Dutch clusters to develop initiatives for pre-competitive cooperation between business sectors and knowledge institutes, six highly promising areas were identified: namely, Flowers and Food; High-tech Systems and Materials; Water; Chemistry; Creative Industry; and Pensions and Social Insurance (Innovatieplatform 2010). Other European countries had already preceded the Netherlands. Finland, for example, had already shifted its economic strategy towards innovation in new sectors by means of an Innovation Platform as far back as 1987. Their approach has proven to be very successful, particularly with regard to the economic successes of Nokia. Similar to the working of population in Finland and other Northern European countries, the majority of people in the Netherlands are active in the services sector. Multinationals are mostly active in the areas of manufacturing and services. In addition, the Netherlands has a large transport and logistics sector owing to its strategic location and well-developed port functions. Private R\&D further localizes in a limited number of large companies. About half of those companies are not, or are only partly, Dutch, but even the large Dutch companies decide about their investment in R\&D on an international level. Although global developments strongly influence the management of these firms, and as such, the functioning of the entire Dutch market, until 2000 the Netherlands did not have a clear global competitiveness strategy. A stronger focus on innovation and sector differentiation in the way it was introduced by the Innovation Platform could be the basis for such a strategy. An important aspect of this strategy is also the stimulation of cooperation between the private, academic and public sector in the sphere of the NIS literature. Increasingly, network coordinators, a concept introduced by Leydesdorff and Etzkowitz (2001), were introduced to serve as bridge builders between the different domains. Further, within the six key areas, pre-competitive cooperation was stimulated and performed by means of a number of innovation programmes. The initiative for most of these programmes is in the hands of large companies and research groups. For SMEs, innovation initiatives were mainly organized through various trade organizations. In 2004, in order to also stimulate actual contact between SMEs and knowledge institutes, the 'innovation voucher' was launched. At the end of 2009, 28,400 vouchers were distributed that allowed SMEs to buy research and advice from knowledge institutes in the Netherlands and a selection of European knowledge institutes on a first-come first-served basis (Innovatieplatform 2010).

\subsection{The Dutch SME sector}

In 2010, there were 847,100 firms in the Netherlands with less than 100 employees (including firms without employees and family members). Together they employed about 3.6 million people. The majority of firms are active in the financial and services sector (219,000 in 2010), followed by the construction sector (114,700 in 2010) (EIM 2011). The majority of those firms are active in the domestic market or trade sporadically with neighbouring countries like Germany. In some sectors, competition is high, for example in construction or cleaning. Other sectors have firms that serve their own regional or local market, for example the car industry or health care. This strong local or regional dimension is characteristic of the SME sector in the Netherlands. In the 
Netherlands, $31 \%$ of the SMEs have marketed new products or services in the past 3 years, and another $31 \%$ of the SMEs indicated that they cooperated with other firms or knowledge institutions in 2010. Only $13 \%$ of the SMEs were involved in some form of international cooperation. On a European scale, the Netherlands performs just below the top collaborators Belgium, Denmark, Finland and Sweden (de Backer et al. 2008). As well as by means of trade organizations and innovation vouchers, innovation among SMEs is stimulated through subsidies on labour costs for researchers (WSBO), and through other intermediary organizations like Syntens, which advises SMEs on behalf of the Dutch government. International concerns have so far been most visible in different forms of pre-competitive cooperation with academics. Sometimes trade organizations were the initiators of such cooperation forms (as in chemistry), but in some, cases regions also played a leading role, like in the case of Brabant in the field of high-tech systems (Brainport Eindhoven). Programmes in these sectors are generally also more focused on open innovation and the inclusion of SMEs. In other sectors, like services, the SME sector is more difficult to involve in innovation initiatives. For these SMEs, initiatives like the innovation voucher were introduced to stimulate innovation and connection with knowledge institutes on a more individual level. However, evaluation of the programme (Dialogic 2008) found that, in particular, innovative SMEs took part in the programme, while less innovative firms ended up not using their voucher due to time constraints or change of strategy. Therefore, those SMEs that participated in the innovation voucher programme and used their voucher in our view represent a specific type of SMEs that are highly innovative and network-driven, and, as such, serve as an ideal population for the research of innovation activities through collaboration and service-based components in both the exploration and exploitation phase. Many studies have shown that SMEs tend to have a higher R\&D productivity than larger firms (although there is considerable variation by industry: see Audretsch and Vivarelli 1996. Yet, there is still little examination of the embeddedness of innovation in SMEs (Shaw 1998; Paniccia 1998), which is often related to their material and resource factor disadvantages. The growing policy attention for the role of SMEs in innovation (also related to their large overrepresentation in national economies) prompts the questions how innovation in SMEs can be facilitated, and which factors contribute to the success (or failure) of their innovation efforts (Lee et al. 2010). In particular, inter-firm collaboration is important for SMEs with limited complementary assets who need to leverage their technology externally (Lichtenthaler 2005). Networking represents another possible form of collaboration, with many researchers claiming that the success of SMEs compared with their larger competitors is based on their ability to utilize external networks more efficiently (Rothwell and Dodgson 1994). Researchers therefore increasingly argue that future research should focus on the nature of innovation in SMEs and the extent to which open innovation is embedded in such firms (Lee et al. 2010).

\section{Research framework}

This study explores the innovation strategy of innovative Dutch SMEs by means of their sources of innovation (SI), innovation capabilities (IC), innovation performance (IP) and commercialization sources (CS). To supplement the knowledge gap in the existing 
literature, we analyse not only cooperation with external organizations (flows) but also the characteristics of the networks (places). In this section, the general hypotheses of this study will be formulated, and the conceptual research framework will be presented.

\subsection{Innovation capabilities}

The capabilities perspective focuses on how the firm develops its capabilities, and what role they play in the organizational structure (den Hond 1996). Capabilities reside in the know-how, experiences, and skills of the firm's employees and managers (Castanias and Helfat 1991; Kogut and Zander 1992). Some capabilities reside in the individual employees, but most capabilities are shared between groups of employees. Capabilities are integrated in the employees' working routines or in the firm's organizational routines. Capabilities are thus knowledge-based. Their creation is associated with processes of learning, both at the individual and the organizational level. This implies that the creation of capabilities is a lengthy process that requires continuous investments (Dierickx and Cool 1989). Also, the knowledge character of capabilities implies that they are highly tacit. Various researchers and institutions have developed different approaches to audit a firm's IC. Christensen (1995) examined ICs in terms of science research assets, process innovation assets, product innovation assets, and aesthetic design assets. Chiesa et al. (1996) used two methods to assess the innovation capability of an organization: a process audit, and a performance audit. More recently, Yam et al. (2004) adopted a functional approach where the separate functions of an organization were to be evaluated. The capability dimensions are: learning capability; R\&D capability; resource allocation capability; manufacturing capability; marketing capability; organization capability; and strategic planning capability. Evangelista et al. (1997) regard R\&D activities as a central component of firms' innovation activities and as the most intangible form of innovation expenditure. R\&D activities by SMEs usually take the form of new product or services and/or new production or services processes. These activities give a good indication of the ability of the firm to identify, assimilate and exploit knowledge from the environment, to integrate an R\&D strategy, and to transform $R \& D$ results into products.

\subsection{Sources of innovation}

Souitaris (2001) divides the efforts that firms make to establish knowledge flow channels and linkages into two categories: (1) those involving the scanning of external information and (2) those involving cooperation with external organizations. This study focuses on the latter sources of innovation (SI). The literature on innovation systems (Cooke 2001; Lundvall 1992; Nelson 1993) and the triple-helix model (Etzkowitz and Leydesdorff 1997) have both stressed the fundamental role in boosting innovativeness of close interactions among heterogeneous actors such as large firms and SMEs, venture capitalists, end users, universities and other public and private institutions. In the course of their technology sourcing activities, the external knowledge to which firms may seek to gain access may be categorized by type of institution into: knowledge from research institutions, knowledge from universities, and knowledge from consultancy 
firms. There is clear empirical evidence that external knowledge from universities plays a particularly important role in some industries. With respect to the spatial distribution of partners, some authors suggest that external research collaborations should be more frequent and effective among co-located partners, while others emphasize the importance of research links with geographically distant partners in order to get access to global circuits of knowledge creation and diffusion (Belussi et al. 2010). The increasing availability and mobility of knowledge workers, the flourishing of the Internet and venture capital markets, and the broadening scope of possible external suppliers in the present age have all boosted open innovation (Chesbrough 2003). Studies of high-tech industries further show that innovation requires knowledge that is both "global best" and "diverse" (Dahlander and McKelvey 2005). We therefore assume that exploration of new opportunities will be more successful through only an international network than through a local or national network. Thus, we propose that SI in the form of university contact and contact with international network leads to the following hypothesis:

H1 Higher use of sources of innovation leads to higher innovation capabilities of SMEs.

\subsection{Innovation performance}

A firm's heterogeneous resources (including its human, capital, and technological resources) are responsible for the variability observed in its financial returns. These are the firm's specific competencies that contribute substantially to its sales growth and competitive advantage. There is a causal connection between a firm's resources and its (technological) innovation performance (IP). The OSLO Manual (OECD 1997) proposes that IP can be measured by the proportion of sales as a result of technologically new or improved products, that is sales performance. This indicator has been adopted in innovation studies (Evangelista et al. 2001). Furthermore, the creation of value depends on the integration of knowledge acquired from universities and flexible forms of cooperation among many different private and public regional and international actors (Cappellin 2010). This requires low cognitive distance or an appropriate absorption capacity (Cohen and Levinthal 1990; Antonelli 2005). The value creation process is also generally facilitated by a lower geographical and/or institutional distance or by a higher accessibility to potential partners (Karlsson 1997; Howells 2002; Boschma 2005; Simmie 2005; Torre and Rallet 2005). Spatial proximity should enable the transfer of tacit knowledge and facilitate the exploitation of knowledge spillovers (Malmberg and Maskell 2005; Maskell 2001). Thus, we propose:

H2 Higher innovation capabilities lead to higher innovation performance of SMEs,

whereby innovation capabilities are formed by both the development of new products or services and new production or services processes, and innovation performance represents both the sales performance of SMEs and proximity to a university (i.e. location). 


\subsection{Commercialization sources}

At the exploration stage, SMEs are most likely to use external partnerships, so they can concentrate on retaining high levels of internal competence in a limited number of technological areas (Narula 2004), whereby they show a preference for networking with public research institutes and universities because of the fear of giving away their technology to competitors (Tidd and Trewhella 1997). At the exploitation stage, SMEs attempt to create value by entering into supplier-customer relations with larger firms (Luukkonen 2005), outsourcing agreements, or strategic alliances with other SMEs (Edwards et al. 2005). Open innovation at the commercialization stage has not been considered seriously in the existing literature (Lee et al. 2010). In general, SMEs consider external sources primarily as a means of getting access to marketing and sales channels at the later stages of innovation (especially the commercialization stage), while open innovation normally focuses more on the early stages of innovation, addressing external technology sourcing and networking with technology providers like universities (Vanhaverbeke and Cloodt 2006). Yet, considering that the market is important in determining successful innovation (Rosenberg and Mowery 1978), and that success in innovation implies successful commercialization, SMEs' innovation can benefit greatly from support at the commercialization stage. Networks can offer clear benefits to SMEs, helping them to decode and appropriate flows of information, such as technological change, sources of technical assistance, market requirements, and strategic choices by other firms, thus strengthening their competitive advantage (Bougrain and Haudeville 2002). We assume that, in the exploitation phase, the proximity of such a network is more important than in the exploration phase. Hypothesis 3 is therefore proposed as follows:

H3 Higher use of commercialization sources leads to higher innovation performance,

whereby the latent variable commercialization sources consist of contact with competitors (i.e. other firms) and active involvement in a national network.

Figure 1 presents the conceptual research framework.

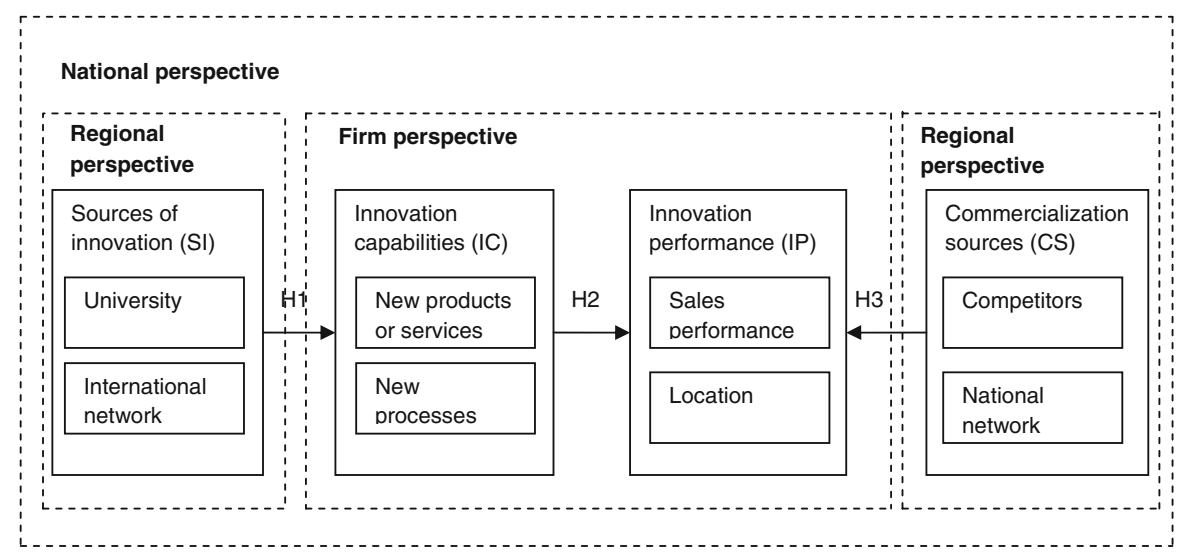

Fig. 1 Conceptual research framework 


\section{Research methodology}

\subsection{Introduction}

The primary analytical technique used in this paper is structural equation modelling (SEM) for validating and testing the theoretical model (using AMOS 18.0 with the maximum likelihood (ML) method). Some tasks relating to linear regression and other analyses are conducted using SPSS 19.0.

\subsubsection{Sources of innovation}

Local institutions such as local universities can be an important source of innovation for firms. For instance, McEvily and Zaheer (1999) found an association between the development of the competitive (innovative) capacities of firms in a cluster and the closeness of the links between firms and the local (regional) institutions. District mechanisms like trust and reputation conditions are generally considered to facilitate the learning process, generating beneficial effects for firms that are part of the district (Exposito-Langa et al. 2011). However, firms must also design distinct strategies to adapt or complement in order to operate under district conditions. In this respect, Bathelt et al. (2004) proposed the notion of 'local buzz' and 'global pipelines' to underline the importance of different firm knowledge bases for a firm's and thus a region's competitiveness. In this study, university and international network are considered sources of innovation for innovative SMEs in the Netherlands in the exploration phase. Respondents were asked to choose from a random sample of innovation sources, which ones they generally contacted for innovation activities. 'University' was one of the options that they could choose. Further, respondents were asked whether their knowledge networks were local, national or international in character, or a combination. Networks were defined in the survey as 'knowledge alliances between organizations and between organizations and knowledge institutions, with knowledge sharing as main objective'.

\subsubsection{Innovation capabilities}

An important innovation capability is a firm's R\&D capability, generally represented by the firm's radical and incremental innovation. Whether a firm focuses on radical or incremental innovations further gives an indication of the firm's learning capability, resource allocation ability, and manufacturing capability. In particular, a high level of radical innovations suggests high learning capability, resource allocation ability and manufacturing capability. In this study, respondents were asked to indicate whether, in the period 2006-2009, they had developed new products or services, improved existing products or services, developed new production or service processes and/or improved existing production or service processes. The new products, services and processes, are considered radical innovations and have been used in the model to represent SMEs' innovation capabilities. 


\subsubsection{Innovation performance}

The performance of any innovation is best measured in financial terms. Financial indices show whether the innovation has had an impact on the market or has been financially successful. Sales performance was measured as the percentage increase in profit sales due to new or improved products, services or processes in the period 20062009. This indicator is widely used in innovation studies (Yam et al. 2011). Further, a region can be understood as a network of inter-organizational relationships where physical proximity and a sense of belonging are decisive elements in facilitating trust, reciprocity, and other common values (Antonelli 2000). We argue that innovation in SMEs is enhanced by university contacts. Proximity to a university can, in the light of the regional literature that highlights proximity (for example, McEvily and Zaheer 1999), be regarded as an advantage for SMEs and will enhance the probability that SMEs cooperate with a university for innovation and thus increase sales performance. In our sample, location is ordinal.

\subsubsection{Commercialization sources}

Further, the model proposes that innovation performance is affected by knowledge of the market. Face-to-face encounters with potential business partners and clients, business representatives and ordinary citizens allow SMEs to get a feel for the market, to gain insight into how business is conducted, and to start building trust (Wilson and Mummalaneni 1990). Further, networks can speed relationships with other firms, small and large, to complement each other's resources at various stages in the value chain (Dana et al. 1999; Jones 1999). A number of private and public initiatives that help SMEs to position themselves in appropriate networks have been developed, and therefore, the role of advisors should not be overlooked. For example, trade associations organize various activities aimed at facilitating contacts between firms. The usefulness of a national network should therefore not be overlooked. Recognizing opportunity and being ready to take advantage of it generally encompasses a temporal element (being in the right place at the right time), a relational element (the unplanned building of networks), and an analytical element (the establishment of connections between actual data and ideas) (Fine and Deegan 1996). We argue in this study that commercialization requires a different network and sources than innovation. In particular, contact with competitors is a good measure of commercialization in order to get a feel for the market and recognize opportunity, either in close cooperation with other firms or through competition.

\subsection{Sample}

The questionnaire specifically focused on Dutch SMEs that had applied for a small or large innovation voucher in the period 2006-2009. Contact details of the SMEs that participated in the scheme were provided for by Agentschap.NL, which is the institution responsible for the innovation voucher scheme on behalf of the Dutch Ministry of Economic Affairs. The innovation voucher allowed an SME to 'buy' research 
time from a selection of Dutch and European knowledge institutes for free. A small voucher of $€ 2,500$ or a large voucher of $€ 7,500$ gave access to research time worth the respective amounts. In the latter case, the SME also contributed $€ 2,500$. Survey questions were partly based on two previous evaluations of the innovation voucher scheme, and based on the British Innovation Survey (BIS 2010). The survey was pretested, which led to several small adjustments in structure in order to avoid complexity. In total, 1,153 SMEs were addressed by regular mail, and 416 questionnaires were returned (a $36 \%$ response rate). The targeted respondent was the owner, manager or R\&D manager of the SME. After the data cleaning process, 243 questionnaires were found to be useful for the SEM analysis. Besides missing values and outliers, this sample focuses particularly on those SMEs that did not only apply but also used the innovation voucher. We believe that in this form, the sample can provide a better representation of innovation in Dutch SMEs.

\section{Data analysis}

\subsection{Construct validation}

Before conducting the hypothesis testing, a thorough measurement analysis was carried out on the instrument to reduce measurement error (Churchill 1979). Discriminant validity and unidimensionality were assessed using confirmatory factor analysis (CFA) (see Table 2). The measurement model constructed for CFA had a relative chi-square value $(\mathrm{cmin} / \mathrm{df})$ of $1.194<3$, an incremental fit index of (IFI) of $0.975>0.9$, and a comparative fit index $(\mathrm{CFI})$ of $0.971>0.9$. The standardized loadings for all constructs, with the exception of location and national network, were sufficiently high $(>0.3)$ for social and behavioural science standards (Merenda 1997). Hair et al. (1998) further note that factor loadings greater than 0.30 are considered to meet the minimum level; loadings of 0.40 are considered more important; and if the loadings are 0.50 or greater,

Table 2 Results of confirmatory factor analysis

\begin{tabular}{lll}
\hline Construct and items & $\begin{array}{l}\text { Standardized } \\
\text { loading }\end{array}$ & Error term \\
\hline Sources of innovation (SI) & & \\
$\quad$ University contact & 0.33 & 0.22 \\
$\quad$ International network & 0.54 & \\
Innovation capabilities (IC) & & \\
$\quad$ New products or services & 0.63 & 0.27 \\
$\quad$ New production or service processes & 0.49 & \\
Innovation performance (IP) & & 0.04 \\
$\quad$ Sales performance & 0.75 & \\
Location & 0.11 & 0.40 \\
Commercialization process (CP) & & \\
Competitors & 0.38 & \\
$\quad$ National network & 0.23 & \\
\hline
\end{tabular}


they are considered practically significant. Consequently, different researchers apply different cut-off values when determining whether a given factor loading is salient. Overall, the research constructs show sufficient unidimensionality, although problems with unidimensionality may occur for the variables 'location' and 'national network'. A check of the modification indices for the measurement model conducted during the CFA process further revealed significant cross-loadings between the variables national network and international network and university contact, which indicated there could be problems with discriminant validity (Kline 1998). The results of the CFA process suggest the removal of the variables 'national network' and 'location' in order to further strengthen the model analysis.

\subsection{Model validation}

The hypotheses were tested by way of structural equation modelling (SEM). Several multiple regression equations can be tested at the same time with SEM, and, it is therefore a very useful tool for testing overall model fit with a lower degree of measurement error. Maximum likelihood estimation (ML) and standardized regression weighting were used for interpretation. The survey data for this study were acceptable for ML-SEM, as the sample met the minimum size requirement of 200 objects (Kelloway 1998). Multiple indices of fit including CFI and cmin/df were used to specify the overall model fit. Within SEM, Joreskog and Sorbom (1986) and Hu and Bentler (1999) suggest some cut-off criteria as follows. All are met or exceeded by the model: the chi-square test statistic is at an insignificant level, or relative chi-square $(\mathrm{cmin} / \mathrm{df})$ is $<2$ if considering the complexity of the model; the Goodness of Fit Index (GFI) and adjusted GFI (AGFI) are over 0.9; the Normed Fit Index (NFI) is over 0.90; the threshold of Comparative Fit Index (CFI) is at the 0.95 level; for the root mean square error of approximation (RSMEA), a benchmark of 0.05 is often used.

\subsection{Sub-hypothesis testing}

The strength of the constructs was further tested by means of sub-hypotheses according to the significance of the t-test of each path, with parameter estimates below 1.0 being made in AMOS by means of conventional regression analysis (see Table 3; Fig. 2). To understand the direct relations of the variables between the constructs, per construct four sub-relations are defined and analysed. To test the strength between the constructs of Hypothesis 1 (higher use of sources of innovation leads to higher innovation capabilities of SMEs), the direct relationships between the underlying variables 'university contact' and 'development of new products or services', 'university contact' and 'development of new production or service processes', 'contact with international network' and 'development of new products or services', and 'contact with and international network' and 'development of new production or service processes' were all found to be significant and positive. The strength of the constructs of Hypothesis 2 (higher innovation capabilities lead to higher innovation performance of SMEs) is tested by means of sub-hypotheses $\mathrm{H} 2 \mathrm{a}-\mathrm{d}$. The relationship between the variables 'development of new products or services' and 'sales performance', and 'development 
Table 3 Results of sub-hypotheses testing

\begin{tabular}{|c|c|c|}
\hline Hypothesis testing & $r$ & Result \\
\hline $\begin{array}{l}\text { H1a: University contact has a positive relationship with the development of } \\
\text { new products or services }\end{array}$ & 0.126 & Accepted \\
\hline $\begin{array}{l}\text { H1b: University contact has a positive relationship with the development of } \\
\text { new production or service processes }\end{array}$ & 0.095 & Accepted \\
\hline $\begin{array}{l}\text { H1c: Contact with an international network has a positive relationship with } \\
\text { the development of new products or services }\end{array}$ & 0.194 & Accepted \\
\hline $\begin{array}{l}\text { H1d: Contact with an international network has a positive relationship with } \\
\text { the development of new production or service processes }\end{array}$ & 0.140 & Accepted \\
\hline $\begin{array}{l}\text { H2a: Development of new products or services has a positive relationship } \\
\text { with sales performance }\end{array}$ & 0.202 & Accepted \\
\hline $\begin{array}{l}\text { H2b: Development of new products or services has a positive relationship } \\
\text { with location }\end{array}$ & n.s. & Rejected \\
\hline $\begin{array}{l}\mathrm{H} 2 \mathrm{c} \text { : Development of new production or service processes has a positive } \\
\text { relationship with sales performance }\end{array}$ & 0.177 & Accepted \\
\hline $\begin{array}{l}\mathrm{H} 2 \mathrm{~d} \text { : Development of new production or service processes has a positive } \\
\text { relationship with location }\end{array}$ & n.s. & Rejected \\
\hline $\begin{array}{l}\text { H3a: Contact with competitors has a positive relationship with sales } \\
\text { performance }\end{array}$ & 0.145 & Accepted \\
\hline $\mathrm{H} 3 \mathrm{~b}$ : Contact with competitors has a positive relationship with location & n.s. & Rejected \\
\hline $\begin{array}{l}\text { H3c: Contact with a national network has a positive relationship with sales } \\
\text { performance }\end{array}$ & n.s. & Rejected \\
\hline $\begin{array}{l}\text { H3d: Contact with a national network has positive relationship with } \\
\text { location }\end{array}$ & n.s. & Rejected \\
\hline
\end{tabular}

n.s. the hypothesis is insignificant and is deleted in the model specification of the structural equation model

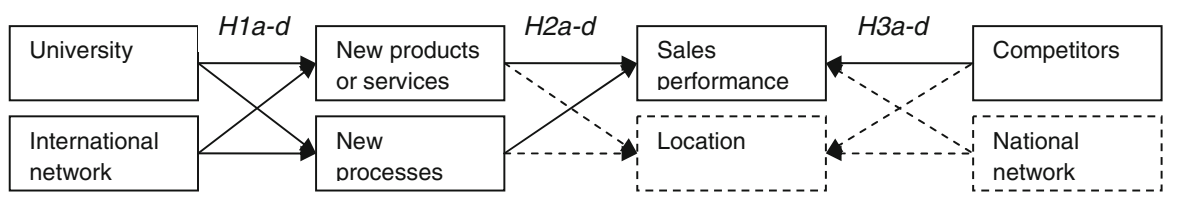

Fig. 2 Overview of sub-hypotheses testing

of new production or service processes' and 'sales performance' is significant and positive. There is, however, no significant relationship between 'development of new products or services' and 'location', and 'development of new production or service processes' and 'location'. As the literature on proximity is also not consistent concerning the importance of proximity for innovation performance (see, e.g., Belussi et al. 2010), we decided not to include the variable 'location' in the performance construct. Finally, the constructs of Hypothesis 3 (higher use of commercialization sources leads to higher innovation performance) are further analysed by means of sub-hypotheses H3a-d. Only the relationship between contact with competitors and sales performance is significant and positive. There are, however, no significant relationships between 'contact with competitors' and 'location', 'national network' and 'location', and 'national network' and 'sales performance'. As the importance of contact with national networks is highlighted in the literature mainly in relation to the proximity of networks (see, e.g., Bougrain and Haudeville 2002), and the importance 


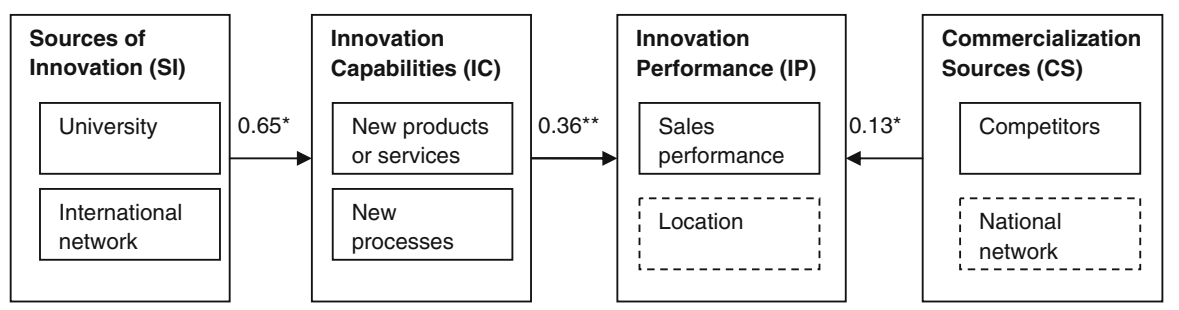

Fig. 3 Structural equation modelling results. $\chi^{2}=4.818 ; \mathrm{df}=8 ; \mathrm{p}=0.777 ; \mathrm{cmin} / \mathrm{df}=0.602$; GFI $=$ $0.995 ; \mathrm{AGFI}=0.988 ; \mathrm{NFI}=0.951 ; \mathrm{CFI}=1.000 ; \mathrm{RSMEA}=0.000 .{ }^{*} p$ value $<0.05 ; * * p$ value $<0.01$

of proximity for innovation performance is being increasingly questioned in the globalized and digitalized economy (see, e.g., Arvidsson and Mannervik 2009), we also deleted 'contact with national network' in our final research model. In Fig. 3, this leads to the following paths whereby the dotted lines represent the insignificant relations. In our structural equation model calculations, 'location' and 'national network' are deleted. Besides their insignificance in the CFA analysis and sub-hypotheses testing, there is insufficient theoretical support to keep them in the model.

\section{Results and discussion}

Table 4 reports the means, standard deviations, and intercorrelations of the variables used in the analysis. The statistics show high correlations between, on the one hand, the development of new products and services, new production and service processes and university contact, international network and sales performance, and, on the other hand, sales performance and contact with competitors. Further, negative correlations appear to exist between university contact and competitors, and international network and competitors. These correlations are insignificant, otherwise they might have supported the existence of different SME efforts with regard to open innovation, whereby SMEs focus either on exploration through contacts with universities and international networks or on exploitation through contact with competitors (Narula 2004; Lee et al. 2010). The overall SEM results are presented in Fig. 2. The unidirectional arrows represent the regression relationship of the connected latent constructs.

Table 4 Descriptive statistics and correlations

\begin{tabular}{|c|c|c|c|c|c|c|c|c|}
\hline & Mean & SD & 1 & 2 & 3 & 4 & 5 & 6 \\
\hline $\begin{array}{l}\text { 1. New products or } \\
\text { services }\end{array}$ & 2.8012 & 0.46102 & 1 & & & & & \\
\hline $\begin{array}{l}\text { 2. New production or } \\
\text { service processes }\end{array}$ & 2.5409 & 0.59550 & $0.307 * *$ & 1 & & & & \\
\hline 3. Sales performance & 4.9942 & 1.97342 & $0.202 * *$ & $0.177 * *$ & 1 & & & \\
\hline 4. Competitors & 1.3480 & 0.47702 & 0.075 & 0.037 & $0.145^{* * *}$ & 1 & & \\
\hline 5. University & 1.2778 & 0.44856 & $0.126^{*}$ & 0.095 & $0.131 *$ & -0.014 & 1 & \\
\hline $\begin{array}{l}\text { 6. International } \\
\text { network }\end{array}$ & 1.2924 & 0.45553 & $0.194 * *$ & $0.140 * *$ & $0.139 *$ & -0.024 & $0.175^{* *}$ & 1 \\
\hline
\end{tabular}


The overall fit indices for this model indicate a good degree of model fit. They yielded an insignificant chi-square $(p=0.777)$, a GFI of 0.995 and a AGFI of $0.988>$ 0.9 , an NFI of $0.951>0.9$, a CFI of $1.000>0.95$, and an RSMEA of $0.000<$ 0.05. The results generally supported the main concept on which the study is based: that the utilization of SI enhances IC, IC affects the IP of the firm, while CS also affects the IP but not the IC or the SI.

\subsection{Impact of utilizing SI on IC}

For Hypothesis 1, we examined the possible direct effects on innovation capabilities (IC) of a firm from sources of innovation (SI). The defined path SI $\rightarrow$ IC appears to be statistically significant. The standardized path coefficient of SI $\rightarrow$ IC is 0.65 $(p<0.010)$, which indicates that IC is immediately and positively influenced by the variance in SI. Hypothesis 1 is thus supported by the sample. The results support previous empirical findings that small innovative firms (which make up the majority of the sample) actively seek diverse partnerships (Larson 1991; Ostgaard and Birley 1994; Soh 2003), and effectively learn from different types of collaborators (Barringer and Jones 2000): in our sample, most specifically from universities. Further, the significance of SI $\rightarrow$ IC supports prior research, which suggests that high-growth firms are twice as likely as low-growth firms to research and enter new markets (Gundry and Welsch 1997; Lohmann 1998). Younger firms are also more likely to expand geographically, using their product line to serve new regional and international markets, while older firms are more likely to grow locally, developing specialized products for small, established demographic niches (Ardishvili and Cardozo 1994). In their study, an international strategy of firms may also be stimulated by their innovation contacts with universities, which usually have a more global network than other types of collaborators. The correlations between the two variables in Table 3 seem to strengthen the existence of such an effect. Broad scanning and timely absorption of new information cues from the external environment thus provide innovative insights (March and Simon 1993) and help firms develop novel technological capabilities (Cohen and Levinthal 1990; Farrell and Doutriaux 1994; Teece et al. 1997). The existing literature also suggests a relation between the use of external sources of information and the improvement of operational routines and production processes (Ostgaard and Birley 1994; Vanhaverbeke et al. 2002; Stuart 2000), which seems supported by the significant path between SI and IC.

\subsection{Effect of IC on IP}

With reference to Hypothesis 2, the factor IC is shown to significantly contribute direct and positive effects to IP (standardized path coefficient $=0.36$ with $p<0.000$ ). Both the development of new products or services and the development of new production or service processes were positively related to the percentage increase in profit sales due to new or improved products, services or processes in the period 2006-2009. Firms need to develop a strong ability to transform an innovative idea into a product, organize the resources required to make it happen, and ultimately manufacture the product. These three steps are the core processes in the development and manufacture of a successful 
new product, service or process. Firms therefore need strong organizational, resource allocation, and manufacturing capabilities to achieve outstanding sales performance. It can be argued here that creative cross-pollination of relevant skills and resources across different areas of expertise (Helfat and Peteraf 2003) depends on the quality and energy of firms' professional personnel (Deeds et al. 1999). High-growth firms engage in more comprehensive activities than slow-growth firms (Gundry and Welsch 1997). High-growth firms pay more attention to periodically updating prior operating routines, upgrade their technology, and retain their production workforce (if any), which affects their innovation performance. Such behaviour avoids the evolvement of core competencies into core rigidities (Leonard-Barton 1992). Location is deleted in the model specification of the structural equation model. Proximity to a (technical) university is insignificant for our sample, which may be caused by the lack of serious geographical distances in the Netherlands. Tödtling et al. (2009) also failed to find particular disadvantages of rural areas or smaller cities for innovation and knowledge interaction. They suggest that Austria, which is similar in size and infrastructure to the Netherlands, has such a well-developed transportation and communication system that locational disadvantages do not exist, and otherwise, they could easily be overcome by the recruitment of personnel, the engagement in distant innovation networks, and the use of modern ICT (Kaufmann et al. 2003).

\subsection{Effect of CS on IP}

The success of innovation performance (IP) of an SME appears to also significantly depend on firms' commercialization sources (CS), in this study represented by contact with competitors, an aspect that often seems neglected in studies on SMEs' open innovation systems (Lee et al. 2010). The standardized path coefficient of CS $\rightarrow$ IP is 0.13 ( $p<0.011)$, which indicates that IP is also immediately and positively influenced by contact with competitors. We thus also find support for Hypothesis 3 . The results provide support for the ideas of Zahra and George (2002) that greater emphasis on market development strategies allows firms to better analyse, interpret, and incorporate novel inputs and ideas into existing operations and offer new solutions that may (indirectly) further enhance the firms innovation capabilities. Effective commercialization of innovative products depends on firms' abilities to delink existing competencies from established product-market combinations and relink them to new product lines and/or new niches (Danneels 2002). Close contact with competitors, or colleague firms, allows SMEs to be at the forefront of new market developments that are taking place, and participate with other firms in innovation cooperation or partnerships. For example, Mangematin et al. 2003 show that biotechnology SMEs typically enter into contracts with big industrial groups or run small projects, manufacturing their own products and marketing them. A development that was already highlighted by Hamel et al. (1989), who also argued that successful companies (in their study primarily Asian) use alliances with competitors not only to avoid investments but to build skills in areas outside the formal agreement and, in this way, systematically diffuse new knowledge throughout their organizations. Our results thus support the argument that success in innovation implies successful commercialization, and that the openness 
of the open innovation model also applies to the commercialization phase (Vanhaverbeke and Cloodt 2006; Lee et al. 2010). National networks may further facilitate such connections through, for example, government support programmes. Mytelka (1991) even suggests that a firm's competitiveness is determined more by its external network than its size. However, this relationship proved to be insignificant for our sample. In a changing global business landscape, spatial distance (in this study represented by contacts with international networks) seems to be gaining ground from spatial proximity as an appropriate measure for successful innovation performance.

\subsection{Effect of RIS on NIS}

With the current SEM model, an attempt is also made to further define and interpret agglomeration economies, that is advantages that arise from the interaction among economic agents made possible by the smaller amount of spatial friction in concentrated locations (Capello 2009). The model shows that the link that is described in the NIS literature between innovation and competitive and economic outcomes at the national level (Porter 1990; Nelson 1993) also exists for Dutch SMEs. Further, it provides empirical support for the theoretical discussions on the composition of innovation actors that dominate the RIS literature. Within the RIS approach, the focus is on the generation and diffusion of knowledge among RIS actors that takes place outside the boundary of the firm. However, not much discussion has yet taken place on how a firm can interact with the RIS to enhance its capacity to innovate and achieve global competitiveness. Yam et al. (2011) have already pointed to this gap in the literature and provided empirical evidence of the bridging function of knowledge-intensive business services, which includes knowledge from research institutions and knowledge from universities, in facilitating the utilization of sources of innovation for technological innovation capabilities enhancement. This study supports these findings but also goes further by showing that these sources of innovation are not necessarily region-bounded. Rather, a combination of local university knowledge and international contacts significantly strengthens SMEs' innovation capabilities. But the generation and diffusion of knowledge does not end there; for successful commercialization, different sources are required to optimize innovation performance. SMEs that have active connections with competitors are more positively linked to innovation performance, probably because they have better insight into the market and its opportunities. Our model thus supports the notion that open innovation in SMEs can indeed be divided into two partstechnology exploration for technological opportunity and technology exploitation for market opportunity. However, our results also show that the underlying conflict that often appears to exist between these two processes according to March (1991) is real, and that the Dutch innovative SMEs in our sample chose to concentrate their resources on either one or the other of these two processes. For SMEs and policy makers, therefore, efforts to stimulate both are indeed essential for successful innovation.

\section{Conclusions}

Increasingly, encouraging innovation in SMEs is central to policy initiatives for stimulating economic development at the local, regional and even national levels 
(Jones and Tilley 2003). Although much is yet unclear about the factors that contribute to the success or failure of the innovation efforts of SMEs, most studies agree that collaboration is particularly important for SMEs which because of their limited complementary assets often need to leverage their technology externally. The concept of open innovation also highlights innovation processes that span firm boundaries, but generally focuses more on larger firms because open innovation is more easily studied there. Larger firms in turn focus mainly on R\&D in open innovation efforts (the exploration phase), while SMEs in general focus more on commercialization. The importance of SMEs' flexibility and specificity for the regional and national innovation system has turned SMEs into useful policy tools. On the basis of the open innovation model, increasingly, SMEs are being stimulated to develop their exploration skills for exploring (technology) opportunity. This was also the aim of the Dutch innovation voucher programme. This development towards policy support of university-industry interaction of SMEs is supported by studies that show that, in the early stages of innovation, firms do indeed benefit from external networks with universities (Tödtling et al. 2009; Kaufmann and Todtling 2001), a finding that is also supported by our analysis. Yet, although open innovation activities may stop here for larger firms, SMEs' innovation can apparently also benefit greatly from external support at the commercialization stage. Our study supports this assumption and shows that for SMEs, the openness of open innovation also applies to the commercialization phase. Policy makers, but also researchers, do not seem to be sufficiently aware of the importance of maintaining an appropriate balance between exploration and exploitation networks for SMEs. Therefore, a subsidy programme like the Dutch 'innovation vouchers' may be regarded with scepticism by SMEs, because it highlights that an exploration network as the "manna from heaven' for successful innovation, while SMEs are generally all too aware that an exploitation network is equally important—something that does not always seem sufficiently recognized. Also, from a research perspective, knowledge interaction at the commercialization phase of the innovation process needs more attention. This study therefore calls for an integrated system of innovation approach that includes both processes of exploration and exploitation.

This study supports the assumptions made in the prior literature that the ability of a firm to exploit knowledge is a critical component of successful innovation. It contributes to the RIS literature by showing how firms can interact with the RIS to enhance their innovation capabilities and innovation performance. In this study, in particular the university and global connections seem to broaden SMEs' creative knowledge horizon and innovation capabilities. Our results further demonstrate that interaction with sources of innovation is important not only in the recognition phase of the innovation process but also at the end stage of the innovation process for the successful commercialization of a product or service. So far, firms' innovation capabilities have been primarily analysed in relationship to external information or external knowledge organizations. Up till now, the commercialization strategy at the other end of the innovation process has been neglected in the study of regional innovation systems and firm innovation systems. This study offers a first attempt to further specify the paths that lead to successful innovation and performance. Further research is necessary to provide a more solid interpretation of the directions of the paths and the characteristics of the firms that benefit from such a strategy. Our sample consists primarily of young and small 
innovative SMEs, and thus, our results do not give insight into prevailing sector structures or other characteristics of the SMEs that could help to further generalize the paths. With the current sample, control variables such as experience and education showed little variation, as most firms were young, and had a more highly educated workforce. The lack of control variables represents a limitation of the study. Second, several variables used in this study were dichtonomous, and this may have affected the strength of the variables in the model, as SEM is designed to deal with continuous or ordinal rather than dichtonomous variables. Finally, contact with a university and contact with competitors were both variables derived from one single question that asked the respondents to indicate what sources they normally used for knowledge about innovation activities. Respondents were allowed to highlight more than one source in the list of sources. The question was specifically intended to gain insight into the firms' everyday use of sources of innovation, and therefore irrespective of the support of government subsidy like the 'innovation voucher programme'. However, in some cases, the answers may be slightly biased. Also, the nature of the relation with the source may vary from respondent to respondent. Follow-up case interviews might have been useful to verify the survey findings, although the theoretical assumptions based on a broad selection of previous studies from different disciplines seem to sufficiently support our findings.

Acknowledgments We greatly acknowledge Agentschap.NL (former SenterNovem) for providing a database with addresses of SMEs that participated in the Dutch 'innovation voucher programme' in the period 2006-2009. In particular, we would like to thank Mr. H. de Groene, Mr. R. van de Walle, Mrs. Christine Lam-Tjabbes and Mr. J. Strange for their time and efforts. Without their active involvement, this research could not have been conducted.

Open Access This article is distributed under the terms of the Creative Commons Attribution License which permits any use, distribution, and reproduction in any medium, provided the original author(s) and the source are credited.

\section{References}

Adler PS, Shenbar A (1990) Adapting your technological base: the organizational challenge. Sloan Manage Rev 25:25-37

Almeida P, Kogut B (1999) Localization of knowledge and the mobility of engineers in regional networks. Manage Sci 45:905-917

Antonelli C (2000) Collective knowledge communication and innovation: the evidence of technological districts. Reg Stud 34:535-547

Antonelli C (2005) Models of knowledge and systems of governance. J Inst Econ 1(1):51-73

Ardishvili A, Cardozo RN (1994) Studying product-market strategies of growing businesses: a case study approach. Frontiers of Entrepreneurship Research, Babson College, Wellesley

Arvidsson N, Mannervik U (2009) The innovation platform. Enabling balance between growth and renewal. VINNOVA, Stockholm

Audretsch D, Vivarelli M (1996) Firm size and R\&D spillovers: evidence from Italy. Small Bus Econ 8:249-258

Barringer BR, Jones FF (2000) A quantitative analysis of firm characteristics and leading practices of rapid-growth entrepreneurial firms. Frontiers of Entrepreneurship Research, Babson College, Wellesley

Bathelt H, Malmberg A, Maskell P (2004) Clusters and knowledge: local buzz, global pipelines and the process of knowledge creation. Human Geogr 28:31-56

Belussi F, Sammarra A, Sedita SR (2010) Learning at the boundaries in an "Open Regional Innovation System": a focus on firms' innovation strategies in the Emilia Romagna life science industry. Res Policy 39:710-721 
BIS (2010) UK innovation survey 2009. Department for Business Innovation \& Skills, London

Boschma RA (2005) Proximity and innovation: a critical assessment. Reg Stud 39(1):61-73

Boschma RA, Frenken K (2006) Why is economic geography not an evolutionary science? Towards an evolutionary economic geography. J Econ Geogr 6:273-302

Bougrain F, Haudeville B (2002) Innovation, collaboration and SMEs internal research capabilities. Res Policy 31:735-747

Boyens K (1998) Externe Verwertung von technologischem Wissen. Deutscher Universitats-Verlag, Wiesbaden

Braczyk HJ, Cooke P, Heidenreich M (1996) Regional innovation systems. UCL, London

Breschi S, Lissoni F (2003) Mobility and social networks: localised knowledge spillovers revisited. CESPRI working paper 142. http://www.cespri.unibocconi.it

Burgelman R, Maidique MA, Weelwright SC (2004) Strategic management of technology and innovation. McGraw, New York

Burger MJ, van Oort FG, Frenken K, van der Knaap B (2009) Networks and economic agglomerations: introduction to the special issue. Tijdschrift voor Economische en Sociale Geografie 100(2):139-144

Capello R (2009) Indivisibilities, synergy and proximity: the need for an integrated approach to agglomeration economies. Tijdschrift voor Economische en Sociale Geografie 100(2):145-159

Cappellin R (2010) The governance of regional knowledge networks. Italian J Reg Sci 9(3):5-41

Carlsson B, Jacobsson S, Holmen M, Rickne A (2002) Innovation system: analytical and methodological issues. Res Policy 31(2):233-245

Castanias RP, Helfat CE (1991) Managerial resources and rents. J Manage 17(1):99-120

Chesbrough HW (2003) Open innovation: the new imperative for creating and profiting from technology. Harvard Business School Press, Cambridge

Chiesa V, Coughlan P, Voss CA (1996) Development of a technical innovation audit. J Prod Innov Manage 13:105-136

Christensen JF (1995) Assets profiles for technological innovation. Res Policy 24:727-745

Churchill GA (1979) A paradigm for developing better measures of marketing constructs. J Market Res 16(2):64-73

Cohen WM, Levinthal DA (1990) Absorptive capacity: a new perspective on learning and innovation. Admin Sci Q 35(1):128-152

Cohen WM, Levinthal DA (1989) Innovation and learning: the two faces of R\&D. Econ J 99:569-596

Colaghirou Y, Kastelli I, Tsakanika A (2004) Internal capabilities and external knowledge sources: complements or substitutes for innovative performance? Technovation 24:29-39

Cooke P (2001) Regional innovation systems, clusters and knowledge economy. Indus Corp Change 10(4):945-974

Cooke P, Uranga MG, Etxebarria G (1997) Regional innovation system:institutional and organizational dimensions. Res Policy 26(4):475-491

Crescenzi R, Rodriguez-Pose A (2011) Innovation and regional growth in the European Union. Springer, Berlin

Cyert RM, March JG (1963) Behavioral theory of the firm. Prentice-Hall Inc, New Jersey

Dahlander L, McKelvey M (2005) The occurence and spatial distribution of collaboration: biotech firms in Gothenburg, Sweden. Technol Anal Strat Manage 17:409-431

Dana L-P, Etemad H, Wright R (1999) The impact of globalisation on SMEs. Global Focus 11(4):93-105

Danneels E (2002) The dynamics of product innovation and firm competencies. Strat Manage J 23:10951121

Davis JL, Harrison SS (2001) Edison in the boardroom: how leading companies realize value from their intellectual assets. Wiley, New York

de Backer K, Lopez-Bassois V, Martinez C (2008) Open innovation in a global perspective-what do existing data tell us?. OECD, Paris

Deeds DL, DeCarolis D, Coombs JE (1999) Dynamic capabilities and new product development in high technology ventures: an empirical analysis of new biotechnology firms. J Bus Ventur 15:211-229

den Hond F (1996) In search of a useful theory of environmental strategy: a case study on the recycling of end-of-life vehicles from the capabilities perspective. VU University Amsterdam, Dissertation

Dialogic (2008) Evaluatie innovatievoucherregeling 2005/2006. Dialogic, Utrecht

Dierickx I, Cool K (1989) Asset stock accumulation and sustainability of competitive advantage. Manage Sci 35(12):1504-1511

Dodgson M (1993) Organizational learning: a review of some literature. Organ Stud 14(3):375-394 
Doloreux D (2002) What we should know about regional innovation systems of innovation. Technol Soc 24:243-263

Edwards T, Delbridge R, Munday M (2005) Understanding innovation in small and medium-sized enterprises: a process manifest. Technovation 25:1119-1120

EIM (2011) Kerncijfers. Kennissite MKB en Ondernemerschap. http://www.ondernemerschap.nl

Eliasson G (2000) Industrial policy, competence blocs and the role of science in economic development. J Evol Econ 10:217-241

Emery FE, Trist EL (1965) The causal texture of organizational environments. Human Relat 18:21-32

Etzkowitz H, Leydesdorff L (1997) Universities in the global economy: a triple helix of universityindustry-government relations. Cassell Academic, London

Evangelista R, Iammarino S, Mastrostefano V, Silvani A (2001) Measuring the regional dimension of innovation: lessons from the Italian innovation survey. Technovation 21(11):733-745

Evangelista R, Perani G, Raptit F, Archibugi D (1997) Nature and impact of innovation in manufacturing: some evidence from the Italian Innovation Survey. Res Policy 26:521-536

Exposito-Langa M, Molina-Morales FX, Capo-Vicedo J (2011) New product development and absorptive capacity in industrial districts: a multidimensional approach. Reg Studies 45(3):319-331

Farrell CA, Doutriaux JA (1994) Collaborative strategies and internal development: when are they most appropriate for small Canadian high-tech firms and why?. Frontiers of Entrepreneurship Research, Babson College, Wellesley

Fine G, Deegan J (1996) Three principles of serendip: insight, chance and discovery in qualitative research. Qual Stud Educ 9(4):434-447

Ford D, Ryan C (1981) Taking technology to market. Harv Bus Rev 59:117-126

Garvin DA (1993) Building a learning organization. Harv Bus Rev 78-91

Geels FW (2004) From sectoral systems of innovation to socio-technical systems: insights about dynamics and change from sociology and institutional theory. Res Policy 33(6/7):897-920

Giuliani E (2007) The selective nature of knowledge networks in clusters: evidence from the wine industry. J Econ Geogr 7:139-168

Grönroos C (1982) An applied service marketing theory. Eur J Market 16(7):30-41

Grönroos C (2006) What can a service logic offer marketing theory? In: Lusch RF, Vargo SL (eds) The service dominant logic of marketing: dialog, debate, and directions. ME Sharpe, New York, pp 354-364

Gundry LK, Welsch HP (1997) Ambitious entrepreneur: attributes of firms exhibiting high growth strategies. Frontiers of Entrepreneurship Research, Babson College, Wellesley

Hair JF, Anderson RE, Tatham RL, Black WC (1998) Multivariate data analysis. Prentice Hall, Upper Saddle River

Hamel G, Doz YL, Prahalad CK (1989) Collaborate with your competitors—and win. Harv Bus Rev 67(1): 133-139

Helfat CE, Peteraf MA (2003) The dynamic resource-based view: capability life-cycles. Strat Manage J 24:997-1010

Hitt MA, Ireland RD, Lee H (2000) Technological learning, knowledge management, firm growth and performance: an introduction essay. J Eng Technol Manage 17(3/4):231-246

Howells JR (2002) Tacit knowledge, innovation and Economic geography. Urban Stud 39(5/6):871-884

Hu L-T, Bentler PM (1999) Cutoff criteria for fit indexes in covariance structure analysis: conventional criteria versus new alternatives. Struct Eq Model 6(1):1-55

Huber G (1991) Organizational learning: the contribution processes and a review of the literature. Organ Sci 2(1):88-117

Innovatieplatform (2010) 2007-2010. Innovatieplatform, Den Haag

Jones M (1999) The internationalisation of small high technology firms. J Int Market 7(4):15-41

Jones O, Tilley F (2003) Competitive advantage in SMEs: organizing for innovation and change. Wiley, Chichester

Joreskog KG, Sorbom D (1986) LISREL VI: analysis of linear structural relationships by maximum likelihood, and least squares methods (program manual). Scientific Software, Mooresville

Karlsson C (1997) Product development, innovation networks, and agglomeration economies. Ann Reg Sci 31(3):235-258

Katz RL, Kahn D (1966) The social psychol of organizations. Wiley, Hoboken

Kaufmann A, Todtling F (2001) Science-industry intercation in the process of innovation: the importance of boundary-crossing between systems. Res Policy 30:791-804 
Kaufmann A, Lehner P, Todtling F (2003) Effects of the internet on the spatial structure of innovation networks. Inform Econ Policy 15:402-424

Kelloway EK (1998) Using LISREL for structural equation modeling: a researcher's guide. Sage Publications, Thousand Oaks

Klepper S (2007) Disagreements, spinoffs, and the evolution of Detroit as the capital of the US automobile industry. Manage Sci 53:616-631

Kline RB (1998) Principles and practice of structural equation modeling. The Guilford Press, New York

Kogut B, Zander U (1992) Knowledge of the firm, combinative capabilities, and the replication of technology. Organ Sci 3(3):383-397

Koschatzky K, Kulicke M, Zenker A (eds) (2000) Innovation networks. ISI, Heidelberg

Kumaresan N, Miyazaki K (1999) An integrated network approach to system of innovation-the case of robotics in Japan. Res Policy 28:563-585

Larson A (1991) Partner networks: leveraging external ties to improve entrepreneurial performance. J Bus Vent 6(3):173-188

Lee S, Park G, Yoon B, Park J (2010) Open innovation in SMEs_-an intermediated network model. Res Policy 39:290-300

Leonard-Barton D (1992) The factory as a learning laboratory. Sloan Manage Rev 34(1):23-38

Leydesdorff L, Etzkowitz H (2001) The transformation of university-industry-governmnent relations. J Sociol. http://www.sociology.org/content/vol005.004/th.html (online)

Lichtenthaler U (2005) External commercialization of knowledge: review and research agenda. Int J Manage Res 7:231-255

Lin C, Tan B, Chang S (2002) The critical factors for technology absorptive capacity. Indus Manage Data Syst 6(102):300-308

Lohmann D (1998) Strategies of high growth firms in adverse public policy and economic environments. Frontiers of Entrepreneurship Research, Babson College, Wellesley

Lundvall BA (1992) National systems of innovation. Pinter, London

Luukkonen T (2005) Variability in organisational forms of biotechnology firms. Res Policy 34:555-570

Malmberg A, Maskell P (2005) Localized learning revisited. DRUID working paper no. 05-19

Mangematin V, Lemarie S, Boissin J-P, Catherine D, Corolleur F, Corolini R (2003) Development of SMEs and heterogeneity of trajectories: the case of biotechnology in biotechnology firms. Res Policy 32:737-750

March JG (1991) Exploration and exploitation in organizational learning. Organ Sci 2(1):71-87

March J, Simon H (1993) Organizations. Blackwell, Cambridge

Maskell P (2001) Towards a knowledge-based theory of the geographic cluster. Indus Corp Change 10:919-941

McEvily B, Zaheer A (1999) Bridging ties: a source of firm heterogeneity in competitive capabilities. Strat Manage J 20:1133-1158

Merenda PF (1997) A guide to the proper use of factor analysis in the conduct and reporting of research: pitfalls to avoid. Measure Eval Counsel Dev 30:156-164

Morgan K, Nauwelaers C (1999) Regional innovation strategies. The Stationary Office, London

Morrison A (2008) Gatekeepers of knowledge within industrial districts: who they are, how they interact. Reg Stud 42:817-835

Moulaert F, Sekia F (2003) Territorial innovation models: a critical survey. Reg Stud 37(3):289-302

Mytelka L (1991) Crisis, technological change and the strategic alliance. In: Mytelka L (ed) Strategic partnerships and the world economy. Printer, London, pp 7-34

Narula R (2004) R\&D collaboration by SMEs: new opportunities and limitations in the face of globalisation. Technovation 25:153-161

Nelson R (1993) National innovation systems. Oxford University Press, Oxford

Norman R, Ramirez R (1993) Designing interactive strategy: from value chain to value constellation. Harv Bus Rev 71:65-77

Normann R (2001) Reframing business: when the map changes the landscape. Wiley, Chichester

Normann R, Ramirez R (1998) Designing interactive strategy. Wiley, Chichester

OECD (1999) Managing national innovation systems. OECD, Paris

OECD (1997) Proposed guidelines for collecting and interpreting technological innovation data. OSLO, Paris

Ostgaard TA, Birley S (1994) Personal networks and firm competitive strategy: a strategic or coincidental match? J Bus Vent 9(4):281-305 
Paniccia I (1998) One, a hundred, thousands of industrial districts. Organizational variety in local networks of small and medium-sized enterprises. Organ Stud 19(4):667-699

Polanyi M (1969) Knowing and geing. Routledge, London

Ponds R, van Oort FG, Frenken K (2007) The geographical and institutional proximity of research collaborations. Papers Reg Sci 86:423-443

Porter ME (1985) Competitive advantage: creating and sustaining superior performance. The Free Press, New York

Porter ME (1980) Competitive strategy: techniques for analyzing competitors and industries. The Free Press, New York

Porter ME (1990) The competitive advantage of nations. McMillan Press Ltd, London

Putnam RD (2000) Bowling alone: the collapse and revival of American community. Simon \& Schuster, New York

Ramirez R, Wallin J (2000) Prime movers. Wiley, Chichester

Rivette KG, Kline D (2000) Rembrandts in the Attic: unlocking the hidden value of patents. Harvard Business School Press, Boston

Romijn H, Albaladejo M (2002) Determinants of innovation capability in small electronics and software firms in Southern England. Res Policy 31:1053-1067

Rosenberg N, Mowery D (1978) The influence of market demand upon innovation: a critical review of some recent empirical studies. Res Policy 8(2):102-153

Rothwell R, Dodgson M (1994) Innovation and size of firm. In: Dodgson M (ed) Handbook of industrial innovation. Edward Elgar, Aldershot, pp 310-324

Schilling A, Werr A (2009) Managing and organizing for innovation in service firms - a literature review with annotated bibliography. VINNOVA, Stockholm

Schumpeter JA (1934) The theory of economic development. Harvard University Press, Cambridge

Shaw E (1998) Social networks: their impact on the innovative behaviour of small service firms. Int J Innov Manage 2(2):201-222

Simmie J (2005) Innovation and space: a critical review of the literature. Reg Stud 39(6):789-804

Soh PH (2003) The role of networking alliances in information acquisition and its implications for new product performance. J Bus Vent 18:727-744

Souitaris V (2001) External communication determinants of innovation in the context of a newly industrialized country: a comparison of objectives and perceptual results from Greece. Technovation 21(1):25-34

Stuart T (2000) Interorganizational alliances an the performance of firms: a study of the growth and innovation rates in a high-technology industry. Strat Manage J 21(8):791-811

Teece DJ (1996) Firm organization, industrial structure, and technological innovation. J Econ Behav Organ 31:193-224

Teece DJ, Pisano G, Shuen A (1997) Dynamic capabilities and strategic management. Strat Manage J 18(7):509-533

Tidd J, Trewhella M (1997) Organizational and technological antecedents for knowledge creation and learning. R\&D Manage 27:359-375

Tödtling F, Trippl M (2005) One size fits all? Towards a differentiated regional innovation policy approach. Res Policy 34:1203-1219

Tödtling F, Lehner P, Kaufmann A (2009) Do different types of innovation rely on specific kinds of knowledge interactions? Technovation 29:59-71

Torre A, Rallet A (2005) Proximity and localization. Reg Stud 39(1):47-60

Uzun A (2001) Technological innovation activities in Turkey: the case of manufacturing industry, 1995-1997. Technovation 21:189-196

Uzzi B (1996) The sources and consequences of embeddedness for the economic performance of organizations: the network effect. Am Sociol Rev 61:674-698

van de Ven AH, Angel HL, Poole MS (1989) Research on the management of innovation: the Minnesota studies. Harper and Row, New York

Vanhaverbeke W, Cloodt M (2006) Open innovation in value networks. In: Chesbrough H, Vanhaverbeke W, West J (eds) Open innovation: researching a new paradigm. Oxford University Press, New York

Vanhaverbeke W, Duysters G, Noorderhaven N (2002) External technology sourcing through alliances or acquisitions: an analysis of the application-specific integrated circuits industry. Organ Sci 13(6):714-733

Visser J, Hemerijck A (1997) 'A Dutch Miracle' Job Growth. Amsterdam University Press, Amsterdam, Welfare Reform and Corporatism in the Netherlands 
Wilson D, Mummalaneni V (1990) Bonding and commitment in buyer-seller relationships: a preliminary conceptualisation. In: Ford D (ed) Understanding business markets: interaction, relationships, networks. Academic Press, London, pp 408-420

Yam CM, Guan JC, Pun KF, Tang PY (2004) An audit of technological innovation capabilities in Chinese firms: some empirical findings in Beijing, China. Res Policy 33(8):1123-1250

Yam RC, Lo W, Tang EP, Lau AK (2011) Analysis of sources of innovation, technological innovation capabilities, and performance: an empirical study of Hong Kong manufacturing industries. Res Policy 40:391-402

Zahra SA, George G (2002) Absorptive capacity: a review, reconceptualization, and extension. Acad Manage Rev 27(2):185-203 